\title{
REVIEW
}

\section{Clinical review: Respiratory failure in HIV-infected patients - a changing picture}

\author{
Putul Sarkar ${ }^{*}$ and Husham F Rasheed ${ }^{2}$
}

\begin{abstract}
Respiratory failure in HIV-infected patients is a relatively common presentation to ICU. The debate on ICU treatment of HIV-infected patients goes on despite an overall decline in mortality amongst these patients since the AIDS epidemic. Many intensive care physicians feel that ICU treatment of critically ill HIV patients is likely to be futile. This is mainly due to the unfavourable outcome of HIV patients with Pneumocystis jirovecii pneumonia who need mechanical ventilation. However, the changing spectrum of respiratory illness in HIV-infected patients and improved outcome from critical illness remain under-recognised. Also, the awareness of certain factors that can affect their outcome remains low. As there are important ethical and practical implications for intensive care clinicians while making decisions to provide ICU support to HIV-infected patients, a review of literature was undertaken. It is notable that the respiratory illnesses that are not directly related to underlying HIV disease are now commonly encountered in the highly active antiretroviral therapy (HAART) era. The overall incidence of P.jirovecii as a cause of respiratory failure has declined since the AIDS epidemic and sepsis including bacterial pneumonia has emerged as a frequent cause of hospital and ICU admission amongst HIV patients. The improved overall outcome of HIV patients needing ICU admission is related to advancement in general ICU care, including adoption of improved ventilation strategies. An awareness of respiratory illnesses in HIV-infected patients along with an appropriate diagnostic and treatment strategy may obviate the need for invasive ventilation and improve outcome further. HIV-infected patients presenting with respiratory failure will benefit from early admission to critical care for treatment and support. There is evidence to suggest that continuing or starting HAART in critically ill HIV patients is beneficial and hence should be considered after multidisciplinary discussion. As a very high percentage (up to 40\%) of HIV patients are not known to be HIV infected at the time of ICU admission, the clinicians should keep a low threshold for requesting HIV testing for patients with recurrent pneumonia.
\end{abstract}

\section{Introduction}

During the HIV epidemic in the early 1980s, critical illness in HIV infected patients was associated with poor prognosis with very high mortality and morbidity. Since then there has been debate on the role of the ICU in the management of HIV patients. Use of such resources for HIV patients has often raised ethical and economical questions. Respiratory failure needing invasive mechanical ventilation in HIV-infected patients remains an indicator for poor outcome and often poses a challenge to intensive care physicians making decisions about aggressive ICU support. Most ICUs are reluctant to

\footnotetext{
*Correspondence: putulsarkar@gmail.com

${ }^{1}$ Consultant in Intensive Care Medicine and Anaesthesia, Epsom and St Helier University Hospitals NHS Trust, St Helier Hospital, Carshalton, Surrey, UK Full list of author information is available at the end of the article
}

provide multiple organ support to critically ill HIV patients.

As the controversy on ICU care of HIV patients goes on, a review of the published literature (identified by searching Medline, Uptodate, Pubmed, EMBASE and CINAHL) was undertaken with particular attention given to respiratory complications in this group of patients. The main aim of this review is to provide an overview of changing outcome and disease patterns in HIV patients presenting with respiratory failure. We believe this review will update ICU physicians with factors related to ICU outcomes in HIV patients at the current time and provide guidance to make appropriate decisions while approaching such cases.

\section{Reasons for ICU admission of HIV patients}

HIV-infected patients might be admitted to ICU for many reasons (Table 1). Acute respiratory failure has remained the most common cause for ICU admission in 


\begin{tabular}{l}
$\begin{array}{l}\text { Table 1. Reasons for ICU admission of HIV-infected } \\
\text { patients in the HAART era }\end{array}$ \\
\hline Respiratory failure \\
Sepsis
\end{tabular}

aThere may be significant overlap of these conditions during acute presentation. ${ }^{b}$ In HIV patients with tuberculosis/cryptococcus infection on highly active antiretroviral therapy (HAART).

HIV patients. It is the presenting symptom in 25 to $50 \%$ of HIV cases, pneumonia being the most common ICU admission diagnosis [1-10]. Sepsis is emerging as an increasingly common cause for ICU admission in HIV patients, shown to range from 33 to $50 \%$ of cases in recent studies. Admission diagnosis of sepsis in HIV patients is independently associated with hospital mortality $[10,11,12]$.

HIV patients may still present to ICU with severe Pneumocystis jirovecii pneumonia despite decreased incidence of such infection after introduction of Pneumocystis prophylaxis in 1989 and highly active antiretroviral therapy (HAART) in 1996. The percentage of AIDS cases having $P$. jirovecii infection declined from $53 \%$ in 1989 to 42\% in 1992 (Centers for Disease Control and Prevention, AIDS Surveillance Summaries, 1989 to 1992). The later use of HAART further reduced the rates of $P$. jirovecii among adults by $3.4 \%$ per year [13]. Overall, opportunistic infections and AIDS-related illness are responsible for a smaller proportion of ICU admissions and are most commonly seen in patients with a new HIV diagnosis [4,6,14-16].

Other causes of ICU admission include central nervous system dysfunction in 11 to $27 \%$, gastrointestinal bleeding in 6 to $15 \%$, cardiovascular dysfunction in 8 to 13\%, and other causes [1-2,5-8]. The immune reconstitution inflammatory syndrome (IRIS) and complications of HAART therapy may also indicate ICU admission. Initiation of HAART results in paradoxical tuberculosis (TB)-IRIS in approximately 20 to $25 \%$ of HIV patients being treated for TB or cryptococcal meningitis [17-19]. This is due to exaggerated inflammatory response against concurrent opportunistic infection.

Although the rate of hospitalization has decreased significantly amongst HIV-infected patients, the ICU admission rate has remained constant or has increased [7,20,21]. Approximately 5 to $12 \%$ of HIV-infected patients admitted to hospitals require intensive care. This seems to be associated with either a new diagnosis of HIV on admission or not being on HAART [7,20-23].

With the advent of HAART in 1996, HIV has now become a chronic disease. These patients are living longer and more likely to present to hospitals with co-morbid conditions and non-AIDS related illnesses. In studies from the HAART era, nearly half of ICU admissions in HIV patients were for non-HIV related critical illness $[2,4,5,10,11,22]$.

It is notable that approximately 25 to $40 \%$ of critically ill HIV-infected patients were not known to be HIV infected at the time of ICU admission in recent studies [7,14,22]. Also, many HIV-infected patients (up to 50\%) are not on HAART at the time of ICU admission [11,14,22,24].

\section{Changing outcome of HIV-infected patients}

The outcome of HIV-infected patients needing ICU support has improved since the AIDS epidemic. Studies in the pre-HAART era showed poor outcomes for such patients from critical illness, with the mortality rate ranging between $70 \%$ and $91 \%$. The worst outcomes were seen in ventilated patients $[25,26]$. In the era of HAART, the reported in-hospital mortality for HIV/AIDS patients admitted to ICU is approximately 25 to $40 \%$, with a median critical care length of stay of 5 to 11 days [4-7].

It is clear that ICU mortality is related to the reason for ICU admission in HIV patients. The highest mortality rates are associated with respiratory failure and sepsis. In these patients, mortality rates remained as high as 50 to $68 \%[2,5,27,28]$. For patients admitted to the ICU for other HIV-related illnesses, the reported mortality is generally lower.

Overall hospital mortality from $P$. jirovecii-related respiratory failure seems to be gradually decreasing over time. Studies after the mid-1990s reported an in-hospital survival rate of up to $50 \%[1-4,6]$ and up to $75 \%$ in one series [8]. One study confirmed nearly $40 \%$ hospital survival in HIV patients with $P$. jirovecii infection requiring mechanical ventilation [29]. Improved survival of $75 \%$ versus $37 \%$ has been reported in HIV patients with severe $P$. jirovecii on HAART compared with those not on HAART, respectively [30]. In addition, other factors are likely to contribute to better outcomes, including low tidal volume ventilation for acute lung injury, early treatment for sepsis, and other general improvements in delivery of ICU care over the past decade [31,32].

Recent studies reported good short and long-term outcome of HIV-infected patients which is comparable to that of non-HIV ICU patients [9,16,24,33-37]. One study found no difference in crude hospital mortality $(44 \%$ versus $46 \%$ ) between HIV and non-HIV patients with lung injury [38]. Predictors of 1-year mortality for HIVinfected patients admitted to the ICU in the HAART era were non-HIV-related.

\section{The on-going ICU dilemma}

Despite improvement in ICU outcome in the HAART era, there is wide variation in the approach of ICU 
physicians towards patients with HIV or AIDS. A survey of Italian ICUs has shown that the admission of patients with HIV or AIDS is perceived as appropriate in only 30.4 and $14.3 \%$ of ICUs, respectively [39]. A US study showed that HIV-infected patients with sepsis were less likely to be admitted to the ICU (37\% versus 56\%; $P<0.0001)$ than those without HIV [40]. Patients with severe sepsis without HIV/AIDS were universally more likely to be admitted to the intensive care unit, even when they had comorbid illnesses with equal or worse expected in-hospital mortality (for example, metastatic cancer).

The reluctance to admit HIV-infected patients to ICU may be because studies persistently reported need for mechanical ventilation as the main predictor of mortality in these patients $[2,5,8,15,16,23,30,31,33,35,37]$. Also, this group of patients demonstrates significantly higher rates of developing ventilator-associated pneumonia compared to non-HIV patients needing mechanical ventilation [41]. However, admission to ICU was recently shown to be independently associated with increased survival in HIVinfected patients [22]. Intensive care physicians need to be aware of improving outcomes in this group of patients while making decisions on ICU support.

\section{Respiratory complications in HIV-infected patients} HIV patients are at high risk of developing lung disease of infectious and non-infectious etiology, which is the main cause of morbidity and mortality in this group $[2-11,23,42,43]$. The spectrum of respiratory disorders associated with HIV infection has changed over the past decade with bacterial pneumonia, sepsis or non-infective respiratory complications emerging as frequent causes of critical illness [9-11]. A recent US study reported that chronic obstructive pulmonary disease and bacterial pneumonia were the most common lung diseases seen in patients with HIV and the incidence was much higher than in non-HIV patients [44].

\section{Differential diagnosis of respiratory complications in HIV patients}

Respiratory illnesses in HIV-infected patients include both infectious and non-infections conditions (Table 2). Each of these infections or neoplasms has a characteristic clinical and radiographic presentation. However, there may be considerable overlap of these conditions during acute illness.

\section{Respiratory failure due to infective causes Pneumocystis jirovecii pneumonia}

P. jirovecii was a common and rapid cause of death in persons living with AIDS in the early years of the HIV epidemic [45]. It still remains a cause for life threatening opportunistic infection [46,47] and a real concern in patients without adequate access to optimal medical care.
Table 2. Differential diagnosis of respiratory complications in HIV patients

\begin{tabular}{|c|c|}
\hline Infectious conditions & Non-infectious conditions \\
\hline $\begin{array}{l}\text { Bacteriala }^{\mathbf{a}} \\
\quad \text { Streptococcus pneumoniae } \\
\text { Staphylococcus aureus } \\
\text { Haemophilus influenzae } \\
\text { Pseudomonas aeruginosa } \\
\text { Klebsiella pneumoniae }\end{array}$ & $\begin{array}{l}\text { Chronic obstructive pulmonary } \\
\quad \text { disease, emphysema } \\
\text { Acute or chronic bronchitis } \\
\text { Bronchiectasis } \\
\text { Pulmonary arterial hypertension } \\
\text { Asthma }\end{array}$ \\
\hline $\begin{array}{l}\text { Fungal }^{\mathrm{b}} \\
\text { Pneumocystis jiroveci } i^{\mathrm{b}} \\
\text { Cryptococcus neoformans }^{\mathrm{b}} \\
\text { Histoplasma capsulatum } \\
\text { Coccidioides immitis } \\
\text { Aspergillus }\end{array}$ & $\begin{array}{l}\text { Lymphocytic interstitial } \\
\text { pneumonitisc } \\
\text { Non-specific interstitial pneumonia } \\
\text { Illicit drug-induced lung disease } \\
\text { Medication-induced lung disease }\end{array}$ \\
\hline $\begin{array}{l}\text { Mycobacterial } \\
\text { Mycobacterium tuberculosis } \\
\text { Mycobacterium kansasii } \\
\text { Mycobacterium avium complex }\end{array}$ & $\begin{array}{l}\text { Immune reconstitution } \\
\text { inflammatory syndrome } \\
\text { Bronchiolitis obliterans with } \\
\text { organizing pneumonia } \\
\text { Sarcoidosis }\end{array}$ \\
\hline $\begin{array}{l}\text { Virus } \\
\text { Cytomegalovirus } \\
\text { Herpes simplex virus }\end{array}$ & $\begin{array}{l}\text { Foreign body granulomatosis } \\
\text { HIV-related neoplasms } \\
\text { Kaposi sarcoma }\end{array}$ \\
\hline $\begin{array}{l}\text { Parasites } \\
\quad \text { Toxoplasma gondib }\end{array}$ & $\begin{array}{l}\text { Non-Hodgkin lymphoma } \\
\text { Primary effusion lymphoma } \\
\text { Lung cancer }{ }^{\mathrm{b}}\end{array}$ \\
\hline
\end{tabular}

${ }^{a}$ AIDS defining if patient with HIV has two or more episodes of bacterial pneumonia within 12 months. ${ }^{b}$ AIDS defining conditions. 'AIDS defining in children aged $<13$ years and not applicable to adults.

Even now about 200 new cases a year are diagnosed in the UK and it can still be fatal, particularly in people who have their HIV diagnosed very late. Before the widespread use of prophylaxis, it was estimated that up to $80 \%$ of people with AIDS would eventually develop $P$. jirovecii infection [48]. Use of prophylaxis against $P$. jirovecii and HAART have dramatically reduced the incidence of this infection [13,49]. The current rate of pneumocystis infection in the HIV-infected population in the developed world is about 10 to $20 \%$.

$P$. jirovecii is distributed worldwide [50]. A high exposure to the organism has been noticed and more than $75 \%$ of children are found to be seropositive by the age of 4 years. This makes asymptomatic pneumocystis infection extremely common. A post-mortem study conducted in Chile of 96 persons who died of unrelated causes found $68 \%$ of them had P. jirovecii in their lungs [51]. It is believed that the organism is transmitted early in life by the aerosol route and remains in a latent state unless the patient becomes immunocompromised [52]. However, this theory of latency has come under question. While carriers may be agents for airborne transmission of the organism, re-infection with different genotypes probably occurs with as much regularity as reactivation of endogenous organisms [53]. It only occurs in an immunocompromised host and, in the absence of any other reason for being immunocompromised, $P$. jirovecii may be the first clue to a new AIDS diagnosis [54]. 
Before the HAART era started, the incidence of P. jirovecii in HIV-infected patients increased as CD4 count decreased. Generally, it did not occur until the CD4 count dropped below 200 cells $/ \mathrm{mm}^{3}$ [55-58]. However, the incidence of $P$. jirovecii in developed countries has greatly decreased since approximately 1988. This appears to have resulted from both recommendations for primary prophylaxis against the infection in patients with CD4 cell counts $<200 / \mu$ land widespread adoption of HAART [13,55,59-62]. In populations that do not have access to preventive treatment, $P$. jirovecii continues to be a major cause of death in HIV-infected patients.

$P$. jirovecii pneumonia is generally gradual in onset and characterized by fever, cough and progressive dyspnea [63]. Other symptoms include fatigue, chills, chest pain, and weight loss. In up to $25 \%$ of these patients chest radiographs are initially normal. The most common radiographic abnormalities are diffuse, bilateral, interstitial, or alveolar infiltrates [64]. Less common presentations include pneumothorax, lobar or segmental infiltrates, cysts, nodules and pleural effusions [63,65].

The two most common abnormal laboratory values associated with $P$. jirovecii infection in HIV patients are a CD4 count below 200 cells $/ \mathrm{mm}^{3}$ and an elevated lactate dehydrogenase level (LDH) $[58,66,67]$. LDH levels appear to reflect the degree of lung injury and are usually elevated above $220 \mathrm{U} / \mathrm{L}$ in about $90 \%$ of such patients. This test has a high sensitivity (78 to $100 \%$ ) but a much lower specificity. However, consistently elevated LDH levels during treatment may indicate therapy failure and a worse prognosis $[46,48,50,66,67]$.

When possible, a definite diagnosis of $P$. jirovecii should be made by documentation of the organism in respiratory specimens. The most simple, rapid and least invasive method of diagnosing pneumocystis is by analysis of induced sputum. While the specificity of this method approaches $100 \%$, the sensitivity ranges from 55 to $92 \%$ $[68,69]$. A high diagnostic sensitivity can be achieved with induced sputum with a good technique and bronchoscopy may need to be done less frequently. However, the limitations of induced sputum include the need for a skilled team, the experience of the centre and the laboratory methods employed $[69,70]$. Endotracheal aspirates from intubated and ventilated patients appear to have a high sensitivity for the detection of $P$. jirovecii [71].

Bronchoalveolar lavage (BAL) is a common procedure used in the ICU to diagnose $P$. jirovecii, having a diagnostic yield that exceeds 90\% [72]. However, it has been suggested that the diagnostic sensitivity of BAL in patients using aerosolized pentamidine prophylaxis may be as low as $62 \%$ [73]. In these patients, trans-bronchial biopsy, which has a diagnostic yield of up to $100 \%$, can be added, but this method is associated with complications. Site-directed lavage, which involves sampling the most heavily involved lobes on chest radiograph, can also increase the yield in patients with focal infiltrate [74]. Since the prevalence of pneumocystis infection has decreased and infection with other organisms is common, we feel BAL should be considered as a diagnostic procedure in suspected HIV patients with respiratory complications, particularly if induced sputum is negative.

Pneumocystis colonization is widespread and is well documented [50-54,75,76]. Hence, distinguishing colonization from infection is not easy. Studies looking at the utility of PCR in diagnosing $P$. jirovecii from sputum and BAL specimens have yielded sensitivities ranging from 81 to $100 \%$ and specificities of 86 to $100 \%$ [77-79]. Various studies over the past decade have documented limited specificity of positive PCR in respiratory specimens and discrepancies between positive PCR and negative staining results have been reported. The false positive PCR was mostly due to $P$. jirovecii colonization [80-85]. A meta-analysis documented that $31.8 \%$ of the patients with false-positive PCR results had prior or later $P$. jirovecii pneumonia, suggesting these false-positive results should be regarded as true-positive results [86]. Quantitative PCR, as against conventional PCR, demonstrates potential for distinguishing colonization from infection, but clinical validation is required [82,87-89].

High resolution computed tomography (HRCT) has a high sensitivity and specificity for diagnosing pneumocystis infection, particularly when the presence of patchy or nodular ground-glass attenuation was used to indicate this [90-92]. HRCT is useful in patients with suspected $P$. jirovecii who have a normal, equivocal, or non-specific chest X-ray finding. A negative HRCT may allow exclusion of $P$. jirovecii pneumonia in such patients.

Arterial blood gas analysis is a useful test, particularly in symptomatic HIV patients who have normal chest Xray. The presence of $P$. jirovecii pneumonia is highly unlikely if the response to exercise is normal, that is, a decrease in the alveolar-arterial oxygen gradient or an increase in oxygen saturation with exercise [93]. This test is useful for screening for $P$. jirovecii.

\section{Bacterial pneumonia}

Bacterial pneumonia is a common cause of acute illness in HIV patients and is among the most common causes of respiratory failure resulting in ICU admission [2,6,14,20,21,37,94-96]. Centres for Disease Control and Prevention $(\mathrm{CDC})$ added recurrent bacterial pneumonia (two or more episodes in a 12-month period) as AIDS defining [96].

Data on the incidence of bacterial pneumonia in HIV patients are mixed [30,37,94-96]. The annual incidence ranges from 5.5 to 29 per 100 person-years, compared with 0.7 to 10 per 100 person-years in non-HIV patients $[20,21,97]$. 
Risk factors for bacterial pneumonia include advanced immunosuppression, interruption of antiretroviral therapy, smoking, intravenous drug use and pre-existing lung disease. Bacterial pneumonia can occur at any stage of HIV infection but tends to occur frequently in individuals with advanced immunosuppression, particularly when the CD4 count drops below 200 cells/ $\mu \mathrm{l}[21,98,99]$. HIV patients that smoke have a two- to five-fold increased risk of developing bacterial pneumonia compared to nonsmoker HIV patients $[21,100]$. The incidence of bacterial pneumonia has decreased significantly in the HAART era $[95,101]$ and interruption in HAART is associated with an increased incidence [100]. The traditional risk factors that may be associated with pneumonia include preexisting lung disease, neutropenia, steroid therapy, or malnutrition [102].

The most common pathogens causing communityacquired pneumonia in HIV patients are Streptococcus pneumoniae, Haemophilus influenzae and Staphylococcus aureus, with S. pneumoniae accounting for the majority of cases in which a bacterial pathogen is isolated $[98,103]$. The incidence of recurrent and invasive pneumococcal disease is higher in HIV patients than in the general population $[21,95,96,104,105]$. This may be partially explained by a predisposition for pneumococcal nasopharyngeal colonization in such patients [106,107]. Legionella infection, although uncommon, occurs approximately 40 times more frequently in HIV patients than in the general population. Although relatively rare, rapidly progressing necrotizing pneumonia can be caused by community-onset methicillin-resistant $S$. aureus, usually harbouring the PVL (Panton-Valentine leukocidin) virulence factor $[108,109]$. These cases are associated with high rates of morbidity and mortality. Nosocomial pneumonia in HIV-infected patients is most commonly caused by $S$. aureus and Gram-negative organisms.

The occurrence of bacterial pneumonia in HIV-infected patients is associated with a permanent decline in pulmonary function and a two- to five-fold increase in long-term mortality compared with non-HIV patients $[21,104,110]$. It has been reported that bacterial pneumonia was associated with permanent reduction in FEV1, FVC, FEV1/FVC, and the diffusing capacity of carbon monoxide [104]. This study concluded that both Pneumocystis carinii pneumonia and bacterial pneumonia result in expiratory airflow reductions that persist after the acute infection resolves. These changes contribute to chronic lung disease (for example, chronic obstructive pulmonary disease) in HIV-infected patients [44].

\section{Tuberculosis, cytomegalovirus and other infections in HIV patients}

Millions of people worldwide are infected with both HIV and TB, especially in developing countries. The World
Health Organization reported in 2010 that there were 8.8 million new cases of $\mathrm{TB}$, of which 1.1 million were among people living with HIV. About $24 \%$ of all TB deaths were associated with HIV [111]. In the United States, HIV-associated TB is most common among intravenous drug users and in Africa it is the most common pulmonary complication of HIV [112,113].

In addition, infection caused by endemic fungi, parasites and viral pathogens contribute substantially to the morbidity and mortality of this population worldwide. Cryptococcus, Histoplasma and Aspergillus, cytomegalovirus (CMV) and Toxoplasma gondii have all been associated with acute respiratory failure in HIV patients, although the risk and predictors of acute respiratory failure for these pathogens are unknown.

The clinical and pathogenic significance of CMV infection has been questioned, although autopsy findings of many HIV patients that died of respiratory failure had evidence for CMV pneumonitis [114-116]. CMV is not commonly found as the sole pathogen in respiratory specimens and it occurs as a concomitant infection with $P$. jirovecii. Positive culture or PCR for CMV in a respiratory specimen does not correlate with clinical or radiological abnormalities, or with acute morbidity due to pulmonary disease $[117,118]$. Many such patients with $P$. jirovecii and CMV infection get better with proper treatment of pneumocystis without specific anti-CMV treatment. However, the presence of concomitant CMV infection with $P$. jirovecii may indicate poor prognosis for long-term survival [119].

\section{Non-infective causes of respiratory failure}

Non-infectious pulmonary diseases, including lung cancer and emphysema, are important causes of morbidity and mortality in HIV patients. The incidence of Kaposi sarcoma and AIDS-related lymphoma has decreased in the HAART era, but compared with the general population, the risk of these malignancies and pulmonary hypertension is still very high in HIV patients [43]. In addition, organizing pneumonia, sarcoidosis, drug hypersensitivity, primary effusion lymphoma, foreign body granulomatosis, and other forms of lung disease can occasionally develop in HIV-infected patients.

The immune reconstitution syndrome can affect the lung and mimic other conditions such as infections and even lung cancer [120]. Lymphocytic interstitial pneumonitis, a rare interstitial lung disease in the general population, is seen with increased frequency in HIV-infected individuals, particularly children. Use of HAART is associated with reduction in some non-infectious pulmonary complications, most likely as a result of immune reconstitution [121].

\section{Factors affecting ICU and hospital outcome}

Intensive care clinicians need to be aware of the factors affecting outcome in HIV-infected patients. Mechanically 
ventilated HIV patients are twice as likely to die in the ICU compared to non-HIV patients [41]. The need for invasive mechanical ventilation and duration of ventilation remains a predictor of ICU and hospital mortality in this group [2,5,8,15,16,31,33-35,37]. A US study in the 1990s observed that $81 \%$ of patients who had P. jirovecii pneumonia and needed mechanical ventilation died [122].

The rate of ventilator-associated pneumonia is significantly higher among HIV patients than the non-HIV population [41]. It has been reported that the majority of HIV patients who received non-invasive positive pressure ventilation (NIV) avoided intubation and had lower rates of pneumothorax [123]. Hence, early intervention with NIV or continuous positive airway pressure (CPAP) seems useful and appropriate in patients with $P$. jirovecii pneumonia. Outcome for HIV patients without any known AIDS-defining condition needing either NIV or invasive mechanical ventilation is reported to be good [124]. Corticosteroid therapy instituted within 24 to 72 hours of $P$. jirovecii therapy has been shown to prevent the initial deterioration often seen in patients with $P$. jirovecii and to reduce the rate of respiratory failure and death [125].

Delayed ICU admission, for example, a time interval from hospital admission to ICU admission of more than 24 hours, is associated with increased mortality in critically ill HIV patients $[10,34,37]$. Admission of such patients to ICU was recently found to be independently associated with increased survival [22].

Other factors independently associated with poor outcome are the presence of sepsis [10-12,27,28], increasing age and severity of illness $[12,28,33,35]$ and vasopressor use $[24,37,126]$. Evidence of hypoalbuminaemia, weight loss and decreased functional status are associated with high mortality risk in HIV patients needing ICU care $[5,6,10,22,33,127]$. Low CD4 count $\left(<200 / \mathrm{mm}^{3}\right)$ and high viral load may not be associated with short-term ICU mortality but are associated with in-hospital and long-term mortality at 1 year $[8,24,35,41]$.

Presence of pneumothorax is thought to be an ominous sign and is associated with poor outcome in these patients. Pneumothorax occurs in 1 to $2 \%$ of hospitalized HIV patients and is associated with 30 to $34 \%$ mortality [4,128-131]. Several investigators reported that extensive tissue invasion within the alveolar interstitium is common in severe $P$. jirovecii infection, and is an important factor in causing necrosis and subsequent pneumothorax $[132,133]$. The administration of aerosolized pentamidine has also been implicated in the pathogenesis of cavitation and pneumothorax [130]. Pleural effusion is seen in 7 to $27 \%$ of hospitalized patients with HIV infection; the three leading causes are parapneumonic effusions, TB and Kaposi sarcoma. The prognosis of patients with pleural
Kaposi sarcoma and non-Hodgkin lymphoma in AIDS remains poor, and the major goal of treatment is palliation [128].

\section{Use of HAART in HIV patients admitted to ICU}

Clinical trials and meta-analysis have definitely shown that HAART improves survival and reduces AIDSrelated complications in patients with advanced disease even when they present with acute opportunistic infections $[134,135]$. In addition, there is growing interest in understanding how HAART may decrease immune activation and positively impact other comorbidities, such as cardiovascular, kidney and liver disease. Consequently, many guidelines from around the world now recommend routine initiation of HAART when CD4 count decreases below 350 cells $/ \mathrm{mm}^{3}$ [136].

Initiation of HAART within 14 days of starting treatment for the opportunistic infection has been shown to reduce progression of AIDS and death when compared with delayed initiation of HAART [137]. Mortality was also significantly lower among those started on HAART during treatment for TB rather than delaying HAART until treatment was complete [138]. However, these studies did not include critically ill HIV patients.

Starting HAART in critically ill HIV patients admitted to ICU is debatable. Recent studies reported that up to $50 \%$ of HIV patients are not on HAART at the time of ICU admission [11,14,22,24]. The lifesaving role of HAART has led to questions concerning the potential treatment of patients with HIV infection in the ICU with HAART. At the moment there are no randomized clinical trials evaluating the safety, efficacy, and timing of starting HAART in the ICU setting and there is no consensus guideline to help make such decisions.

Some valid concerns persist regarding administration of antiretroviral therapy in HIV patients in the ICU, such as the possibility of unpredictable medication absorption, variable drug levels, and the potential for medication toxicities and drug interactions [139]. Paradoxical worsening of the underlying respiratory failure can also result from IRIS to pneumocystis pneumonia, TB, or other mycobacterial disease after the initiation of antiretroviral therapy. Manifestations of IRIS that can result in critical illness include pneumonitis, acute respiratory distress syndrome, meningitis, hepatitis, pancreatitis, pericarditis and lactic acidosis [17-19,139-146]. In addition, some studies observed that ICU mortality was not different when comparing patients receiving effective HAART with those not on HAART $[15,16,36,37]$.

However, findings of some recent studies suggest that use of HAART in the ICU may be associated with better outcome and stopping HAART in ICU is not beneficial $[126,147,148]$. HAART use at ICU admission has been associated with higher CD4 cell counts, lower plasma 
HIV RNA levels, higher serum albumin, and lower proportions with AIDS-associated ICU admission [16]. HAART was also associated with a decreased risk of bacterial pneumonia [21]. A French study observed that introducing or continuing HAART in the ICU was protective and was associated with better long-term outcome [24]. Any potential toxic side effects like IRIS can be treated with corticosteroids and in most cases HAART can be continued. Deferral of the initiation of HAART to the first 4 weeks of the continuation phase of TB therapy can reduce the risks of adverse effects of HAART without increasing the risk of death [17].

\section{Conclusion}

Respiratory failure is a relatively common presentation in HIV-infected patients, often requiring admission to critical care. Outcomes for such patients have significantly improved since the AIDS epidemic and currently is comparable to that of non-HIV patients. Improving ICU outcome of HIV patients reflects general advancement in management of critical illness in such cases rather than improvements in the management of HIVrelated illnesses. Hence, we feel that HIV patients with respiratory failure will benefit from early admission to critical care.

Patients with severe AIDS-defined disease are less likely to benefit from invasive mechanical ventilation and NIV/CPAP should be the primary consideration. HIV patients with less severe AIDS-related illness and the ones without any known AIDS defining condition should be considered for either NIV or invasive mechanical ventilation, because the outcomes are good in this population. To avoid complications of barotrauma, a lung protective ventilation strategy with low tidal volume and low inspiratory plateau pressures should be adopted similar to patients with acute respiratory distress syndrome.

Whenever possible, samples of induced sputum should be sent for culture, cytology and acid fast bacilli. BAL needs to be considered if the sputum results are inconclusive for organisms. Clinicians should be aware of limited specificity of PCR in respiratory specimens for detection of $P$. jirovecii due to widespread colonisation. HRCT is to be considered if chest X-ray is normal or shows non-specific changes. Serum protein, CD4 T-cell count, HIV RNA viral load and serum LDH should be requested.

In view of the frequent occurrence of bacterial pneumonia and sepsis in HIV patients, prompt administration of broad-spectrum antibiotics should be considered in the initial treatment regime while awaiting results of sputum culture, BAL or PCR. Empirical treatment for $P$. jirovecii with trimethoprim sulpha-methoxazole and steroid should be considered if clinical suspicion of $P$. jirovecii is high. Possibility of active TB, in particular multi-resistant $\mathrm{TB}$, should be ruled out prior to initiation of steroid therapy. Evidence of concomitant CMV infection may be clinically irrelevant and does not need antiCMV treatment if the patient is getting better with treatment for pneumocystis and other infections.

In patients who have been on HAART prior to admission to ICU, this treatment should be continued if possible, provided absorption from the gut seems appropriate. HIV patients that are not on HAART on ICU admission should be considered for this after multidisciplinary discussion and after treating other acute illnesses for 2 weeks. HAART should be deferred for 4 weeks if a patient with HIV has TB and is on anti-TB treatment. However, HAART should be considered as soon as patient starts to tolerate anti-TB treatment (WHO recommendations 2010). Doses of antiretroviral drugs should be adjusted according to renal and liver functions. In the event of a patient developing IRIS due to HAART, corticosteroids should be considered and HAART may be continued.

Intensive care clinicians should keep in mind that a high percentage of HIV patients (up to 40\%) are not known to have HIV prior to admission to critical care. As recurrent bacterial pneumonia is associated with HIV, clinicians should request a HIV test in such patients.

\section{Abbreviations}

BAL, bronchoalveolar lavage; CMV, cytomegalovirus; CPAP, continuous positive airway pressure; HAART, highly active antiretroviral therapy; HRCT, high-

resolution computed tomography; IRIS, immune reconstitution inflammatory syndrome; LDH, lactate dehydrogenase; NIV, non-invasive positive pressure ventilation; $\mathrm{PCR}$, polymerase chain reaction; $\mathrm{TB}$, tuberculosis.

\section{Author details}

'Consultant in Intensive Care Medicine and Anaesthesia, Epsom and St Helier University Hospitals NHS Trust, St Helier Hospital, Carshalton, Surrey, United Kingdom. ${ }^{2}$ Specialist Registrar, General and Renal Medicine, Norfolk and Norwich University Hospitals NHS Trust, United Kingdom.

Published: 14 June 2013

\section{References}

1. Lazard T, Retel O, Guidet B, Maury E, Vallleron AJ, Offenstadt G: AIDS in a medical intensive care unit: immediate prognosis and long term survival. JAMA 1996, 276:1240-1245.

2. Rosen MJ, Clayton K, Schneider RF, Fulkerson W, Rao AV, Stansell J, Kvale PA, Glassroth J, Reichman LB, Wallace JM, Hopewell PC: Intensive care of patients with HIV infection: utilization, critical illness, and outcomes. Pulmonary Complications of HIV Infection Study Group. Am J Respir Crit Care Med 1997, 155:67-71

3. Gill JK, Greene L, Miller R, Pozniak A, Cartledge J, Fisher M, Nelson MR, Soni N: ICU admission in patients infected with the human immunodeficiency virus - a multicentre survey. Anaesthesia 1999, 54:727-732.

4. Afessa B: Pleural effusion and pneumothorax in hospitalized patients with HIV infection: the Pulmonary Complications, ICU support, and Prognostic Factors of Hospitalized Patients with HIV (PIP) Study. Chest 2000, 117:1031.

5. Nickas $\mathrm{G}$, Wachter RM: Outcomes of intensive care for patients with human immunodeficiency virus infection. Arch Intern Med 2000, 160:541-547.

6. Morris A, Creasman J, Turner J, Luce JM, Wachter RM, Huang L: Intensive care of human immunodeficiency virus-infected patients during the era of highly active antiretroviral therapy. Am J Respir Crit Care Med 2002, 166:262-267.

7. Casalino E, Wolff M, Ravaud P, Choquet C, Bruneel F, Regnier B: Impact of 
HAART advent admission patterns and survival in HIV-infected patients admitted to intensive care unit. AIDS 2004, 18:1429-1433.

8. Casalino E, Mendoza-Sassi G, Wolff M, Bedos JP, Gaudebout C, Regnier B, Vachon F: Predictors of short-and long - term survival in HIV-infected patients admitted to ICU. Chest 1998, 113:421-429.

9. Turtle L, Vyakernam R, Menon-Johansson A, Nelson MR, Soni N: Intensive care usage by HIV-positive patients in the HAART era. Interdiscip Perspect Infect Dis 2011:847835.

10. Chiang HH, Hung CC, Lee CM, Chen HY, Chen MY, Sheng WH, Hsieh SM, Sun $\mathrm{HY}, \mathrm{Ho} C \mathrm{CC}, \mathrm{Yu} \mathrm{CJ}$ : Admission to intensive care unit of HIV-infected patients in the era of highly active antiretroviral therapy: etiology and prognostic factors. Crit Care 2011, 15:R202.

11. Japiassú AM, Amâncio RT, Mesquita EC, Medeiros DM, Bernal HB, Nunes EP, Luz PM, Grinsztejn B, Bozza FA: Sepsis is a major determinant of outcome in critically ill HIV/AIDS patients. Crit Care 2010, 14:R152.

12. Greenberg JA, Lennox JL, Martin GS: Outcomes for critically ill patients with HIV and severe sepsis in the era of highly active antiretroviral therapy. J Crit Care 2012, 27:51-57.

13. Kaplan JE, Hanson D, Dworkin MS, FrederickT, Bertolli J, Lindegren ML: Epidemiology of human immunodeficiency virus-associated opportunistic infections in the United States in the era of highly active antiretroviral therapy. Clin Infect Dis 2000, 30(Suppl 1):S5-14

14. Vincent B, Timsit JF, Auburtin M, Schortgen F, Bouadma L, Wolff M, Regnier B Characteristics and outcomes of HIV-infected patients in the ICU: impact of the highly active antiretroviral treatment era. Intensive Care Med 2004 30:859-866

15. Khouli H, Afrasiabi A, Shibli M, Hajal R, Barrett CR, Homel P: Outcome of critically ill human immunodeficiency virus-infected patients in the era of highly active antiretroviral therapy. J Intensive Care Med 2005, 20:327-333.

16. Powell K, Davis JL, Morris AM, Chi A, Bensley MR, Huang L: Survival for patients with HIV admitted to the ICU continues to improve in the current era of combination antiretroviral therapy. Chest 2009, 135:11-17.

17. Abdool Karim SS, Naidoo K, Grobler A, Padayatchi N, Baxter C, Gray AL, Gengiah T, Gengiah S, Naidoo A, Jithoo N, Nair G, El-Sadr WM, Friedland G, Abdool Karim Q: Integration of antiretroviral therapy with tuberculosis treatment. NEngl J Med 2011, 365:1492-1501.

18. Blanc FX, SokT, Laureillard D, Borand L, Rekacewicz C, Nerrienet E, Madec $Y$, Marcy O, Chan S, Prak N, Kim C, Lak KK, Hak C, Dim B, Sin Cl, Sun S, Guillard B, Sar B, Vong S, Fernandez M, Fox L, Delfraissy JF, Goldfeld AE; CAMELIA (ANRS 1295-CIPRA KH001) Study Team: Earlier versus later start of antiretroviral therapy in HIV-infected adults with tuberculosis. N Eng/ J Med 2011 365:1471-1481.

19. Makadzange AT, Ndhlovu CE, Takarinda K, Reid M, Kurangwa M, Gona P, Hakim JG: Early versus delayed initiation of antiretroviral therapy for concurrent HIV infection and cryptococcal meningitis in sub-Saharan Africa. Clin Infect Dis 2010, 50:1532-1538.

20. Hull, MW, Phillips, P, Montaner, JS: Changing global epidemiology of pulmonary manifestations of HIV/AIDS. Chest 2008, 134:1287.

21. Kohli R, Lo Y, Homel P, Flanigan TP, Gardner LI, Howard AA, Rompalo AM, Moskaleva G, Schuman P, Schoenbaum EE; HER Study Grou: Bacterial pneumonia, HIV therapy, and disease progression among HIV-infected women in the HIV epidemiologic research (HER) study. Clin Infect Dis 2006, 43:90-98.

22. Coquet I, Pavie J, Palmer P, Barbier F, Legriel S, Mayaux J, Molina JM, Schlemmer B, Azoulay E: Survival trends in critically ill HIV-infected patients in the highly active antiretroviral therapy era. Crit Care 2010, 14:R107.

23. Beck JM, Rosen MJ, Peavy HH: Pulmonary complications of HIV infection. Report of the Fourth NHLBI Workshop. Am J Respir Crit Care Med 2001, 164:2120.

24. Morquin D, Le Moing V, Mura T, Makinson A, Klouche K, Jonquet O, Reynes J, Corne P: Short- and long-term outcomes of HIV-infected patients admitted to the intensive care unit: impact of antiretroviral therapy and immunovirological status. Ann Intensive Care 2012, 2:25

25. Wachter RM, Luce JM, Turner J, Volberding P, Hopewell PC: Intensive care of patients with the acquired immunodeficiency syndrome. Outcome and changing patterns of utilization. Am Rev Respir Dis 1986, 134:891-896.

26. Schein RM, Fischl MA, Pitchenik AE, Sprung CL: ICU survival of patients with the acquired immunodeficiency syndrome. Crit Care Med 1986, 14:1026-1027.

27. Thyrault M, Gachot B, Chastang C, Souweine B, Timsit JF, Bedos JP, Regnier B, Wolff M: Septic shock in patients with the acquired immunodeficiency syndrome. Intensive Care Med 1997, 23:1018-1023.

28. Rosenberg AL, Seneff MG, Ativeh L, Wagner R, Bojanowski L, Zimmerman JE: The importance of bacterial sepsis in intensive care unit patients with acquired immunodeficiency syndrome: implications for future care in the age of increasing antiretroviral resistance. Crit Care Med 2001, 29:548-556.

29. Randall Curtis J, Yarnold PR, Schwartz DN, Weinstein RA, Bennett CL: Improvements in outcomes of acute respiratory failure for patients with human immunodeficiency virus-related Pneumocystis carinii pneumonia. Am J Respir Crit Care Med 2000, 162:393-398.

30. Morris A, Wachter RM, Luce J, Turner J, Huang L: Improved survival with highly active antiretroviral therapy in HIV-infected patients with severe pneumocystis carinii pneumonia. AIDS 2003, 17:73-80.

31. Miller RF, Allen E, Copas A, Singer M, Edwards SG: Improved survival for HIV infected patients with severe Pneumocystis jirovecii pneumonia is independent of highly active antiretroviral therapy. Thorax 2006, 61:716-721.

32. Davis JL, Morris A, Kallet RH, Powell K, Chi AS, Bensley M, Luce JM, Huang L: Low tidal volume ventilation is associated with reduced mortality in HIVinfected patients with acute lung injury. Thorax 2008, 63:988-993.

33. Adlakha A, Pavlou M, Walker DA, Copas AJ, Dufty N, Batson S, Edwards SG, Singer M, Miller RF: Survival of HIV infected patients admitted to intensive care unit in the era of highly active antiretroviral therapy. Int J STD AIDS 2011, 22:498-504

34. Foo H, Clezy k, Post JJ: The long term outcome of HIV-infected patients after intensive care admission. Int J STD AIDS 2012, 23:e4-8.

35. van Lelyveld SF, Wind CM, Mudrikova T, van Leeuwen HJ, de Lange DW, Hoepelman Al: Short- and long-term outcome of HIV-infected patients admitted to the intensive care unit. Eur J Clin Microbiol Infect Dis 2011, 30:1085-1093.

36. Dickson SJ, Batson S, Copas AJ, Edwards SG, Singer M, Miller RF: Survival of HIV-infected patients in the intensive care unit in the era of highly active antiretroviral therapy. Thorax 2007, 62:964-968.

37. Barbier F, Coquet I, Legriel S, Pavie J, Darmon M, Mayaux J, Molina JM, Schlemmer B, Azoulay E: Etiologies and outcome of acute respiratory failure in HIV-infected patients. Intensive Care Med 2009, 35:1678-1686.

38. Mendez-Tellez PA, Damluji A, Ammerman D, Colantuoni E, Fan E, Sevransky JE, Shanholtz C, Gallant JE, Pronovost PJ, Needham DM: Human immunodeficiency virus infection and hospital mortality in acute lung injury patients. Crit Care Med 2010, 38:1530-1535

39. Corona A, Raimondl F: Critical care of HIV-infected patients:still a dilemma for Italian intensivists-results of multicenter survey. Eur J Anaesthesio/ 2010 27:377-382.

40. Mrus JM, Braun L, Yi MS, Linde-Zwirble WT, Johnston JA: Impact of HIV/AIDS on care and outcomes of severe sepsis. Crit Care 2005, 9:R623-630.

41. Pathak V, Rendon IS, Atrash S, Gagadam VP, Bhunia K, Mallampalli SP, Vegesna $\checkmark$, Dangal MM, Ciubotaru RL: Comparing outcome of HIV versus non-HIV patients requiring mechanical ventilation. Clin Med Res 2012, 10:57-64.

42. Boyton RJ: Infectious lung complications in patients with HIV/AIDS. Curr Opin Pulm Med 2005, 11:203.

43. Kanmogne GD: Noninfectious pulmonary complications of HIV/AIDS. Curr Opin Pulm Med 2005, 11:208.

44. Crothers K, Huang L, Goulet JL, Goetz MB, Brown ST, Rodriguez-Barradas MC, Oursler KK, Rimland D, Gibert CL, Butt AA, Justice AC: HIV infection and the risk of pulmonary diseases in the combination antiretroviral therapy era. Am J Respir Crit Care Med 2011, 183:388-395.

45. Selik Rm, Starcher ET, Curran JW: Opportunistic diseases reported in AIDS patients: frequencies, associations and trends. AIDS 1987, 1:175-182

46. Mocroft A, Katlama C, Johnson AM, Pradier C, Antunes F, Mulcahy F, Chiesi A, Phillips AN, Kirk O, Lundgren JD: AIDS across Europe, 1994-98: the EuroSIDA study. Lancet 2000, 356:291-296.

47. Huang L, Morris A, Limper AH, Beck JM; ATS Pneumocystis Workshop Participants: An Official ATS Workshop Summary: Recent advances and future directions in pneumocystis pneumonia (PCP). Proc Am Thorac Soc 2006, 3:655-664

48. Glatt AE, Chirgwin K, Landesman SH: Treatment of infections associated with human immunodeficiency virus. N Engl J Med 1988, 318:1439-1448.

49. Porter K, Fairley CK, Wall PG, Evans BG, Goldberg DJ, Weerasuriya M, Noone A: AIDS defining diseases in the UK: the impact of $P C P$ prophylaxis and twelve years of change. Int J STD AIDS 1996, 7:252-257.

50. Morris A, Lundgren JD, Masur H, Walzer PD, Hanson DL, Frederick T, Huang L, Beard CB, Kaplan JE: Current epidemiology of pneumocystis pneumonia. 
Emerg Infect Dis 2004, 10:1713-1720.

51. Ponce CA, Gallo M, Bustamante R, Vargas SL: Pneumocystis colonization is highly prevalent in the autopsied lungs of the general population. Clin Infect Dis 2010, 50:347-353.

52. Pifer LL, Hughes WT, Stango S, Woods D: Pneumocystis carinii infection: evidence of high prevalence in normal and immunosuppressed children. Pediatrics 1978, 61:35.

53. Wakefield AE, Lindley AR, Ambrose HE, Denis CM, Miller RF: Limited asymptomatic carriage of Pneumocystis jiroveci in human immunodeficiency virus-infected patients. J Infect Dis 2003, 187:901.

54. Masur H, Michelis MA, Greene JB, Onorato I, Stouwe RA, Holzman RS, Wormser G, Brettman L, Lange M, Murray HW, Cunningham-Rundles S: An outbreak of community-acquired Pneumocystis carinii pneumonia. N Engl J Med 1981, 305:1431-1438.

55. Hoover DR, Saah AJ, Bacellar H, Phair J, Detels R, Anderson R, Kaslow RA: Clinical manifestations of AIDS in the era of pneumocystis prophylaxis. Multicenter AIDS Cohort Study. N Engl J Med 1993, 329:1922.

56. Stansell JD, Osmond DH, Charlebois E, LaVange L, Wallace JM, Alexander BV, Glassroth J, Kvale PA, Rosen MJ, Reichman LB, Turner JR, Hopewell PC: Predictors of pneumocystis carinii pneumonia in HIV-infected persons. Pulmonary Complications of HIV Infection Study Group. Am J Respir Crit Care Med 1997, 155:60-66.

57. Bozzette SA, Finkelstein DM, Spector SA, Frame P, Powderly WG, He W, Phillips $L$, Craven D, van der Horst C, Feinberg J: A randomized trial of three antipneumocystis agents in patients with advanced human immunodeficiency virus infection. NIAID AIDS Clinical Trials Group. NEng J Med 1995, 332:693.

58. Phair J, Muñoz A, Detels R, Kaslow R, Rinaldo C, Saah A: The risk of Pneumocystis carinii pneumonia among men infected with the human immunodeficiency virus type I. Multicenter AIDS cohort study group. NEngl J Med 1990, 322:161-165.

59. Sepkowitz KA: Effect of prophylaxis on the clinical manifestations of AIDSrelated opportunistic infections. Clin Infect Dis 1998, 26:806.

60. Jain MK, Skiest DJ, Cloud JW, Jain CL, Burns D, Berggren RE: Changes in mortality related to human immunodeficiency virus infection: comparative analysis of inpatient deaths in 1995 and in 1999-2000. Clin Infect Dis 2003, 36:1030-1038.

61. Wolff AJ, O'Donnell AE: Pulmonary manifestations of HIV infection in the era of highly active antiretroviral therapy. Chest 2001, 120:1888

62. San-Andrés FJ, Rubio R, Castilla J, Pulido F, Palao G, de Pedro I, Costa JR, del Palacio A: Incidence of acquired immunodeficiency syndrome-associated opportunistic diseases and the effect of treatment on a cohort of 1115 patients infected with human immunodeficiency virus, 1989-1997. Clin Infect Dis 2003, 36:1177.

63. Kales CP, Murren JR, Torres RA, Crocco JA: Early predictors of in-hospital mortality for Pneumocystis carinii pneumonia in acquired immunodeficiency syndrome. Arch Intern Med 1987, 147:1413.

64. DeLorenzo L, Huang CT, Maguire GP, Stone DJ: Roentgenographic patterns of Pneumocystis carinii pneumonia in 104 patients with AIDS. Chest 1987, 91:323.

65. Sepkowitz KA, Telzak EE, Gold JW, Bernard EM, Blum S, Carrow M, Dickmeyer M, Armstrong D: Pneumothorax in AIDS. Ann Intern Med 1991, 114:455-459.

66. Zaman MK, White DA: Serum lactate dehydrogenase levels and Pneumocystis carinii pneumonia: Diagnostic and prognostic significance. Am Rev Respir Dis 1988, 137:796

67. Butt AA, Michaels S, Kissinger $P$ : The association of serum lactate dehydrogenase level with selected opportunistic infections and HIV progression. Int I Infect Dis 2002, 6:178.

68. Zaman MK, Wooten OJ, Suprahmanya B, Ankobiah W, Finch PJ, Kamholz SL: Rapid noninvasive diagnosis of Pneumocystis carinii from induced liquefied sputum. Ann Intern Med 1988, 109:7-10

69. Cruciani M, Marcati P, Malena M, Bosco O, Serpelloni G, Mengoli C: Metaanalysis of diagnostic procedures for Pneumocystis carinii pneumonia in HIV-1-infected patients. Eur Respir J 2002, 20:982-989.

70. Turner D, Schwarz Y, Yust I: Induced sputum for diagnosing Pneumocystis carinii pneumonia in HIV patients: new data, new issues. Eur Respir J 2003, 21:204-208.

71. Alvarez F, Bandi V, Stager C, Guntupalli KK: Detection of Pneumocystis carinii in tracheal aspirates of intubated patients using calcofluor-white (FungiFluor) and immunofluorescence antibody (Genetic Systems) stains. Crit Care Med 1997, 25:948.
72. Bigby TD: Diagnosis of Pneumocystis carinii pneumonia. How invasive? Chest 1994, 105:650-652

73. Jules-Elysee KM, Stover DE, Zaman MB, Bernard EM, White DA: Aerosolized pentamidine: effect on diagnosis and presentation of Pneumocystis carinii pneumonia. Ann Intern Med 1990, 112:750-757.

74. Levine SJ, Kennedy D, Shelhamer JH, Kovacs A, Feuerstein IM, Gill VJ, Stock F, Solomon D, Boylen CT, Masur H: Diagnosis of Pneumocystis carinii pneumonia by multiple lobe, site-directed bronchoalveolar lavage with immunofluorescent monoclonal antibody staining in human immunodeficiency virus-infected patients receiving aerosolized pentamidine chemoprophylaxis. Am Rev Respir Dis 1992, 146:838-843.

75. Fritzsche C, Riebold D, Munk-Hartig A, Klammt S, Neeck G, Reisinger E: High prevalence of Pneumocystis jirovecii colonization among patients with autoimmune inflammatory diseases and corticosteroid therapy. Scand J Rheumatol 2012, 41:208-213.

76. Morris A, Norris KA: Colonization by Pneumocystis jirovecii and its role in disease. Clin Microbiol Rev 2012, 25:297-317

77. Lipschik GY, Gill VJ, Lundgren JD, Andrawis VA, Nelson NA, Nielsen JO, Ognibene FP, Kovacs JA: Improved diagnosis of Pneumocystis carinii infection by polymerase chain reaction on induced sputum and blood. Lancet 1992, 340:203-206.

78. Olsson M, Elvin K, Löfdahl S, Linder E: Detection of Pneumocystis carinii DNA in sputum and bronchoalveolar lavage samples by polymerase chain reaction. J Clin Microbiol 1993, 31:221-226.

79. Torres J, Goldman M, Wheat LJ, Tang X, Bartlett MS, Smith JW, Allen SD, Lee $\mathrm{CH}$ : Diagnosis of Pneumocystis carinii pneumonia in human immunodeficiency virus-infected patients with polymerase chain reaction: a blinded comparison to standard methods. Clin Infect Dis 2000, 30:141-145.

80. Sing A, Trebesius K, Roggenkamp A, Rüssmann H, Tybus K, Pfaff F, Bogner JR, Emminger $C$, Heesemann J: Evaluation of diagnostic value and epidemiological implications of PCR for Pneumocystis carinii in different immunosuppressed and immunocompetent patient groups. J Clin Microbiol 2000, 38:1461-1467.

81. Fischer S, Gill VJ, Kovacs J, Miele P, Keary J, Silcott V, Huang S, Borio L, Stock F, Fahle G, Brown D, Hahn B, Townley E, Lucey D, Masur H: The use of oral washes to diagnose Pneumocystis carinii pneumonia: a blinded prospective study using a polymerase chain reaction-based detection system. J Infect Dis 2001, 184:1485-1488.

82. Fillaux J, Malvy S, Alvarez M, Fabre R, Cassaing S, Marchou B, Linas MD, Berry A: Accuracy of a routine real-time PCR assay for the diagnosis of Pneumocystis jirovecii pneumonia. J Microbiol Methods 2008, 75:258-261.

83. Gupta R, Mirdha BR, Guleria R, Kumar L, Samantaray JC, Agarwal SK, Kabra SK, Luthra K: Diagnostic significance of nested polymerase chain reaction for sensitive detection of Pneumocystis jirovecii in respiratory clinical specimens. Diagn Microbiol Infect Dis 2009, 64:381-388.

84. Hauser PM, Bille J, Lass-Flörl C, Geltner C, Feldmesser M, Levi M, Patel H, Muggia V, Alexander B, Hughes M, Follett SA, Cui X, Leung F, Morgan G, Moody A, Perlin DS, Denning DW: Multicenter, prospective clinical evaluation of respiratory samples from subjects at risk for Pneumocystis jirovecii infection by use of a commercial real-time PCR assay. J Clin Microbiol 2011, 49:1872-1878.

85. Huggett JF, Taylor MS, Kocjan G, Evans HE, Morris-Jones S, Gant V, Novak T, Costello AM, Zumla A, Miller RF: Development and evaluation of a real-time PCR assay for detection of Pneumocystis jirovecii DNA in bronchoalveolar lavage fluid of HIV-infected patients. Thorax 2008, 63:154-159.

86. Lu Y, Ling G, Qiang C, Ming Q, Wu C, Wang K, Ying Z: PCR Diagnosis of Pneumocystis pneumonia: a bivariate meta-analysis. J Clin Microbiol 2011, 49:4361-4363.

87. Mühlethaler K, Bögli-Stuber K, Wasmer S, von Garnier C, Dumont P, Rauch A, Mühlemann K, Garzoni C: Quantitative PCR to diagnose Pneumocystis pneumonia in immunocompromised non-HIV patients. Eur Respir J 2012 39:971-978.

88. Reid AB, Chen SC, Worth LJ: Pneumocystis jirovecii pneumonia in non-HIVinfected patients: new risks and diagnostic tools. Curr Opin Infect Dis 2011, 24:534-544.

89. Botterel F, Cabaret O, Foulet F, Cordonnier C, Costa JM, Bretagne S: Clinical significance of quantifying Pneumocystis jirovecii DNA by using real-time PCR in bronchoalveolar lavage fluid from immunocompromised patients. J Clin Microbiol 2012, 50:227-231.

90. Gruden JF, Huang L, Turner J, Webb WR, Merrifield C, Stansell JD, Gamsu G, 
Hopewell PC: High-resolution CT in the evaluation of clinically suspected Pneumocystis carinii pneumonia in AIDS patients with normal, equivocal, or nonspecific radiographic findings. AJR Am J Roentgenol 1997, 169:967.

91. Hartman, TE, Primack, SL, Muller, NL, Staples, CA: Diagnosis of thoracic complications in AIDS: accuracy of CT. AJR Am J Roentgenol 1994, 162:547.

92. Hidalgo A, Falcó V, Mauleón S, Andreu J, Crespo M, Ribera E, Pahissa A, Cáceres J: Accuracy of high-resolution CT in distinguishing between Pneumocystis carinii pneumonia and non-Pneumocystis carinii pneumonia in AIDS patients. Eur Radiol 2003, 13:1179.

93. Stover DE, Greeno RA, Gagliardi AJ: The use of a simple exercise test for the diagnosis of Pneumocystis carinii pneumonia in patients with AIDS. Am Rev Respir Dis 1989, 139:1343.

94. Afessa B, Green B: Bacterial pneumonia in hospitalised patients with HIV infection:the pulmonary complications, ICU support, and prognostic factors of hospitalised patients with HIV (PIP) Study. Chest 2000, 117:1017-1022

95. Sullivan JH, Moore RD, Keruly JC, Chaisson RE: Effect of antiretroviral therapy on the incidence of bacterial pneumonia in patients with advanced HIV infection. Am J Respir Crit Care Med 2000, 162:64.

96. Afessa B, Green W, Chiao J, Frederick W: Pulmonary complications of HIV infection. Autopsy findings. Chest 1998, 113:1225.

97. 1993 revised classification system for HIV infection and expanded surveillance case definition for AIDS among adolescents and adults. MMWR Recomm Rep 1992, 41:1-19.

98. Hirschtick RE, Glassroth J, Jordan MC, Wilcosky TC, Wallace JM, Kvale PA, Markowitz N, Rosen MJ, Mangura BT, Hopewell PC: Bacterial pneumonia in persons infected with the human immunodeficiency virus. N Eng/ J Med 1995, 333:845-851.

99. López-Palomo C, Martín-Zamorano M, Benítez E, Fernández-Gutiérrez C Guerrero F, Rodríguez-Iglesias M, Girón-González JA: A report in 2006 Pneumonia in HIV-infected patients in the HAART era: incidence, risk, and impact of the pneumococcal vaccination. J Med Virol 2004, 72:517-524.

100. Gordin FM, Roediger MP, Girard PM, Lundgren JD, Miro JM, Palfreeman A, Rodriguez-Barradas MC, Wolff MJ, Easterbrook PJ, Clezy K, Slater LN: Pneumonia in HIV-infected persons: increased risk with cigarette smoking and treatment interruption. Am J Respir Crit Care Med 2008, 178:630.

101. Heffernan RT, Barrett NL, Gallagher KM, Hadler JL, Harrison LH, Reingold AL, Khoshnood K, Holford TR, Schuchat A: Declining incidence of invasive Streptococcus pneumoniae infections among persons with AIDS in an era of highly active antiretroviral therapy, 1995-2000. J Infect Dis 2005, 191:2038.

102. Kaplan JE, Benson C, Holmes KH, Brooks JT, Pau A, Masur H, Centers for Disease Control and Prevention (CDC), National Institutes of Health, HIV Medicine Association of the Infectious Diseases Society of America: Guidelines for prevention and treatment of opportunistic infections in HIV-infected adults and adolescents: recommendations from CDC, the National Institutes of Health, and the HIV Medicine Association of the Infectious Diseases Society of America. MMWR Recomm Rep 2009, 58(RR-4):1.

103. Park DR, Sherbin VL, Goodman MS, Pacifico AD, Rubenfeld GD, Polissar NL, Root RK; Harborview CAP Study Group: The etiology of communityacquired pneumonia at an urban public hospital: influence of human immunodeficiency virus infection and initial severity of illness. J Infect Dis 2001, 184:268-277.

104. Morris AM, Huang L, Bacchetti P,Turner J, Hopewell PC, Wallace JM, Kvale PA Rosen MJ, Glassroth J, Reichman LB, Stansell JD: Permanent declines in pulmonary function following peumonia in human immunodeficiency virus-infected persons. The Pulmonary Complications of HIV Infection Study Group. Am J Respir Crit Care Med 2000, 162:612.

105. Turett GS, Blum S, Telzak EE: Recurrent pneumococcal bacteremia: risk factors and outcomes. Arch Intern Med 2001, 161:2141.

106. Kyaw MH, Rose CE Jr, Fry AM, Singleton JA, Moore Z, Zell ER, Whitney CG; Active Bacterial Core Surveillance Program of the Emerging Infections Program Network: The influence of chronic illnesses on the incidence of invasive pneumococcal disease in adults. J Infect Dis 2005, 192:377.

107. Gill CJ, Mwanakasale V, Fox MP, Chilengi R, Tembo M, Nsofwa M, Chalwe V, Mwananyanda L, Mukwamataba D, Malilwe B, Champo D, Macleod WB, Thea $\mathrm{DM}$, Hamer DH: Impact of human immunodeficiency virus infection on Streptococcus pneumoniae colonization and seroepidemiology among Zambian women. J Infect Dis 2008, 197:1000.

108. Gillet $Y$, Issartel B, Vanhems $P$, Fournet JC, Lina G, Bes M, Vandenesch F,
Piémont Y, Brousse N, Floret D, Etienne J: Association between Staphylococcus aureus strains carrying gene for Panon-Valentine leukocidin and highly lethal necrotising pneumonia in young immunocompetent patients. Lancet 2002, 359:753.

109. Francis JS, Doherty MC, Lopatin U, Johnston CP, Sinha G, Ross T, Cai M, Hansel NN, Perl T, Ticehurst JR, Carroll K, Thomas DL, Nuermberger E, Bartlett JG: Severe community-onset pneumonia in healthy adults caused by methicillin-resistant Stapylococus aureus carrying the Panton-Valentine leukocidin genes. Clin Infect Dis 2005, 40:100-107.

110. Osmond DH, Chin DP, Glassroth J, Kvale PA, Wallace JM, Rosen MJ, Reichman LB, Poole WK, Hopewell PC: Impact of bacterial pneumonia and Pneumocystis carinii pneumonia on human immunodeficiency virus disease progression. Pulmonary Complications of HIV Study Group. Clin Infect Dis 1999, 29:536.

111. World Health Organization HIV/TB Facts 2011 [http://www.who.int/hiv/ topics/tb/hiv_tb_factsheet_june_2011.pdf]

112. Friedman LN, Williams MT, Singh TP, Frieden TR: Tuberculosis, AIDS, and death among substance abusers on welfare in New York City. N Engl J Med 1996, 334:828

113. Corbett EL, Watt CJ, Walker N, Maher D, Williams BG, Raviglione MC, Dye C: The growing burden of tuberculosis: Global trends and interactions with the HIV epidemic. Arch Intern Med 2003, 163:1009-1021.

114. Baughman R: Cytomegalovirus: The monster in the closet? Am J Respir Crit Care Med 1997, 156:1

115. Kim T, Moon SM, Sung H, Kim MN, Kim SH, Choi SH, Jeong JY, Woo JH, Kim YS, Lee SO: Outcomes of non-HIV-infected patients with Pneumocystis pneumonia and concomitant pulmonary cytomegalovirus infection. Scand J Infect Dis 2012, 44:670-677.

116. McKenzie R, Travis WD, Dolan SA, Pittaluga S, Feuerstein IM, Shelhamer J, Yarchoan R, Masur H: The causes of death in patients with Human Immunodeficiency virus infection: A clinical and pathologic study with emphasis on the role of pulmonary diseases. Medicine 1991, 70:326-343.

117. Millar AB, Patou G, Miller RF, Grundy JE, Katz DR, Weller IV, Semple SJ: Cytomegalovirus in the lungs of patients with AIDS. Am Rev Respir Dis 1990, 141:1474-1477.

118. Miles P, Baughman R, Linnemann C: Cytomegalovirus in the bronchoalveolar lavage fluid of patients with AIDS. Chest 1990, 97:1072

119. Hayner CE, Baughman RP, Linnemann CC Jr, Dohn MN: The relationship between Cytomegalovirus retrieved by bronchoalveolar lavage and mortality in patients with HIV. Chest 1995, 107:735-740

120. Stoll M, Schmidt RE: Immune restoration inflammatory syndromes: apparently paradoxical clinical events after the initiation of HAART. Curr HIV/AIDS Rep 2004, 1:122.

121. Mocroft A, Kirk O, Clumeck N, Gargalianos-Kakolyris P, Trocha H, Chentsova N, Antunes F, Stellbrink HJ, Phillips AN, Lundgren JD: The changing pattern of Kaposi sarcoma in patients with HIV, 1994-2003: the EuroSIDA Study. Cancer 2004, 100:2644

122. De Palo VA, Millstein BH, Mayo PH, Salzman SH, Rosen MJ: Outcome of intensive care in patients with HIV infection. Chest 1995, 107:506-510.

123. Confalonieri M, Calderini E, Terraciano S, Chidini G, Celeste E, Puccio G, Gregoretti C, Meduri GU: Noninvasive ventilation for treating acute respiratory failure in AIDS patients with Pneumocystis carinii pneumonia. Intensive Care Med 2002, 28:1233-1238.

124. Duggal A, Rai HS, Nseir B, Cutrona A, Goldstein L: Outcome of HIV patients requiring invasive mechanical ventilation as compared to patients with AIDS. Chest 2009, 136(4_MeetingAbstracts):115S-a-115S.

125. Consensus statement on the use of corticosteroids as adjunctive therapy for pneumocystis pneumonia in acquired immunodeficiency syndrome. The national institutes of Health-University of California Expert Panel for corticosteroids as adjuctive therapy for pneumocystis pneumonia. N Engl J Med 1990, 323:1500-1504.

126. Croda J, Croda MG, Neves A, De Sousa dos Santos S: Benefit of antiretroviral therapy on survival of human immunodeficiency virus-infected patients admitted to an intensive care unit. Crit Care Med 2009, 37:1605-1611.

127. Fei MW, Kim EJ, Sant CA, Jarlsberg LG, Davis JL, Swartzman A, Huang L: Predicting mortality from HIV-associated Pneumocystis pneumonia at illness presentation: an observational cohort study. Thorax 2009, 64:1070-1076.

128. Afessa B: Pleural effusions and pneumothoraces in AIDS. Curr Opin Pulm Med 2001, 7:202

129. Beck JM: Pleural disease in patients with acquired immune deficiency 
syndrome. Clin Chest Med 1998, 19:341.

130. Sepkowitz KA, Telzak EE, Gold JW, Bernard EM, Blum S, Carrow M, Dickmeyer M, Armstrong D: Pneumothorax in AIDS. Ann Intern Med 1991, 114:455-459.

131. Murry CE, Schmidt RA: Tissue invasion by Pneumocystis carinii: a possible cause of cavitary pneumonia and pneumothorax. Hum Pathol 1992 23:1380.

132. Travis WD, Pittaluga S, Lipschik GY, Ognibene FP, Suffredini AF, Masur H, Feuerstein I, Kovacs J, Pass HI, Condron KS, et al:: Atypical pathologic manifestations of Pneumocystis carinii pneumonia in the acquired immune deficiency syndrome. Review of 123 lung biopsies from 76 patients with emphasis on cysts, vascular invasion, vasculitis, and granulomas. Am J Surg Pathol 1990, 14:615.

133. Gutierrez Y: The biology of Pneumocystis carinii. Semin Diagn Pathol 1989, 6:203

134. Hogg RS, Yip B, Chan KJ, Wood E, Craib KJ, O'Shaughnessy MV, Montaner JS: Rates of disease progression by baseline CD4 cell count and viral load after initiating triple-drug therapy. JAMA 2001, 286:2568,

135. SMART Study Group, El-Sadr WM, Grund B, Neuhaus J, Babiker A, Cohen CJ, Darbyshire J, Emery S, Lundgren JD, Phillips A, Neaton J: Risk for opportunistic disease and death after reinitiating continuous antiretroviral therapy in patients with HIV previously receiving episodic therapy: a randomized trial. Ann Intern Med 2008, 149:289.

136. Wilkin TJ, Gullick RM: When to start antiretroviral therapy? Clin Infectious Dis $2008,47: 1580$

137. Zolopa A, Andersen J, Powderly W, Sanchez A, Sanne I, Suckow C, Hogg E, Komarow L: Early antiretroviral therapy reduces AIDS progression/death in individuals with acute opportunistic infections: a multicenter randomized strategy trial. PLOS ONE 2009, 4:e5575.

138. Abdool Karim SS, Naidoo K, Grobler A, Padayatchi N, Baxter C, Gray A, Gengiah T, Nair G, Bamber S, Singh A, Khan M, Pienaar J, El-Sadr W, Friedland G, Abdool Karim Q: Timing of initiation of antiretroviral drugs during tuberculosis therapy. N Engl J Med 2010, 362:697-706

139. Morris A, Masur H, Huang L: Current issues in critical care of the human immunodeficiency virus-infected patient. Crit Care Med 2006, 34:42-49.
140. Narita M, Ashkin D, Hollender ES, Pitchenik AE: Paradoxical worsening of tuberculosis following antiretroviral therapy in patients with AIDS. Am J Respir Crit Care Med 1998, 158:157-161.

141. Wislez M, Bergot E, Antoine M, Parrot A, Carette MF, Mayaud C, Cadranel J: Acute respiratory failure following HAART introduction in patients treated for Pneumocystis carinii pneumonia. Am J Respir Crit Care Med 2001, 164:847-851

142. Goldsack NR, Allen S, Lipman MC: Adult respiratory distress syndrome as a severe immune reconstitution disease following the commencement of highly active antiretroviral therapy. Sex Transm Infect 2003, 79:337-338.

143. Hirsch HH, Kaufmann G, Sendi P, Battegay M: Immune reconstitution in HIV-infected patients. Clin Infect Dis 2004, 38:1159-1166.

144. Miller KD, Cameron M, Wood LV, Dalakas MC, Kovacs JA: Lactic acidosis and hepatic steatosis associated with use of stavudine: report of four cases. Ann Intern Med 2000, 133:192-196.

145. Moore RD, Keruly JC, Chaisson RE: Incidence of pancreatitis in HIV-infected patients receiving nucleoside reverse transcriptase inhibitor drugs. AIDS 2001, 15:617-620.

146. Smith CJ, Olsen CH, Mocroft A, Viard JP, Staszewski S, Panos G, Staub T, Blaxhult A, Vetter N, Lundgren JD: The role of antiretroviral therapy in the incidence of pancreatitis in HIV-positive individuals in the EuroSIDA study. AIDS 2008, 22:47-56.

147. Corona A, Raimondi F: Caring for HIV-infected patients in the ICU in the highly active antiretroviral therapy era. Curr HIV Res 2009, 7:569-579.

148. Meybeck A, Lecomte L, Valette M, Van Grunderbeeck N, Boussekey N, Chiche A, George H, Yazdanpanah Y, Leroy O: Should highly active antiretroviral therapy be prescribed in critically ill HIV-infected patients during the ICU stay? A retrospective cohort study. AIDS Res Ther 2012, 9:27.

doi:10.1186/cc12552

Cite this article as: Sarkar P, Rasheed HF: Clinical review: Respiratory failure in HIV-infected patients - a changing picture. Critical Care 2013, 17:228. 